\title{
Method and timing of grassland renovation affects herbage yield, nitrate leaching, and nitrous oxide emission in intensively managed grasslands
}

\author{
G. L. Velthof · I. E. Hoving · J. Dolfing • \\ A. Smit · P. J. Kuikman · O. Oenema
}

Received: 14 May 2009/Accepted: 9 July 2009/Published online: 15 August 2009

(C) The Author(s) 2009. This article is published with open access at Springerlink.com

\begin{abstract}
Managed grasslands are occasionally ploughed up and reseeded in order to maintain or increase the sward productivity. It has been reported that this renovation of grassland is associated with a flush of soil organic nitrogen $(\mathrm{N})$ mineralization and with a temporary increase in soil mineral $\mathrm{N}$ contents. Here, we report on the effects of method and time of grassland renovation on herbage yield, nitrate $\left(\mathrm{NO}_{3}{ }^{-}\right)$ leaching and nitrous oxide $\left(\mathrm{N}_{2} \mathrm{O}\right)$ emission. Field experiments were carried out at three sites (two sandy soils and a clay soil) in the Netherlands for three years. Renovation of grassland increased the percentage of Perennial ryegrass from $48-70 \%$ up to more than $90 \%$. However, averaged over three years, dry matter yields were higher for the reference (not
\end{abstract}

G. L. Velthof $(\bowtie) \cdot$ A. Smit · P. J. Kuikman .

O. Oenema

Alterra, P.O. Box 47, 6700 AA Wageningen,

The Netherlands

e-mail: gerard.velthof@wur.nl

I. E. Hoving

Animal Sciences Group, P.O. Box 2176,

8203 AD Lelystad, The Netherlands

J. Dolfing

School of Civil Engineering and Geosciences, Newcastle

University, Newcastle NE1 7RU, UK reseeded) swards (on average $13.6 \mathrm{Mg} \mathrm{ha}^{-1}$ for the highest $\mathrm{N}$ application rate) than for the renovated grasslands (12.2-13.1 $\mathrm{Mg} \mathrm{ha}^{-1}$ dry matter). Grassland renovation in April did not increase $\mathrm{N}$ leaching in comparison to the reference. However, renovation in September increased the risk of leaching, because mineral $\mathrm{N}$ contents in the $0-90 \mathrm{~cm}$ were in November on average $46-77 \mathrm{~kg} \mathrm{~N}^{-1}$ higher than in the reference. Contents of dissolved organic N (DON) in the soil were not affected by renovation. Renovation increased $\mathrm{N}_{2} \mathrm{O}$ emissions by a factor of 1.8-3.0 relative to the reference grassland. Emissions of $\mathrm{N}_{2} \mathrm{O}$ were on average higher after renovation in April $\left(8.2 \mathrm{~kg} \mathrm{~N} \mathrm{~N}_{2} \mathrm{O}-\mathrm{N} \mathrm{ha}^{-1}\right)$ than in September $(5.8 \mathrm{~kg}$ $\mathrm{N}_{2} \mathrm{O}-\mathrm{N}$ ha $^{-1}$ ). Renovation without ploughing (i.e. only chemically destruction of the sward) resulted in a lower percentage of perennial ryegrass (60-84\%) than with ploughing (>90\%). Moreover, $\mathrm{N}_{2} \mathrm{O}$ emissions were higher after renovation without ploughing than with ploughing. Clearly, farmers need better recommendations and tools for determining when grassland renovation has beneficial agronomic effects. Losses of $\mathrm{N}$ via leaching and $\mathrm{N}_{2} \mathrm{O}$ emission after renovation can probably not be avoided, but renovation in spring in stead of autumn in combination with ploughing and proper timing of fertilizer application can minimize $\mathrm{N}$ losses.

Keywords Grassland · Nitrogen · Nitrous oxide $\cdot$ Nitrate leaching · Ploughing · Renovation · Yield 


\section{Introduction}

Permanent grasslands are important sources of feed in the intensively managed dairy and beef farming systems in North West Europe. These grasslands are harvested by grazing and cutting (for making silage and hay, and for feeding zero-grazed cattle). Mean grassland yields roughly range between 6 and $14 \mathrm{Mg} \mathrm{ha}^{-1}$ year $^{-1}$, depending on climate, management and fertilization (Whitehead 2000). It has been often observed in practice that yields and quality of permanent grasslands decrease during ageing, because of sward deterioration following extreme weather conditions and/or bad management. As a consequence, many farmers occasionally plough up and reseed these intensively managed grasslands in order to maintain or increase the sward productivity. In the Netherlands, intensively managed grasslands on sandy soils are reseeded on average every five years and those on clayey soils every ten years (Schils et al. 2002). Grassland renovation may both increase the percentage of perennial ryegrass in the sward and enhance soil conditions (e.g. better aeration by ploughing). Reseeding in the second half of the growing season is preferred by most farmers, because the chance of a successful establishment of the sward with low weed infestation is high in this relatively warm and moist period. Moreover, farmers consider loosing a period of grass production in autumn less of a problem than loosing the period of relatively high grass production in spring.

Nitrogen $(\mathrm{N})$ inputs via $\mathrm{N}$ fertilizer and animal manure to intensively managed grasslands are relatively high ( $>200 \mathrm{~kg} \mathrm{~N}^{-1}$; Bos et al. 2005). Grassland has a relatively high $\mathrm{N}$ uptake capacity, both in aboveground and belowground biomass. A fraction of the annual $\mathrm{N}$ input accumulates in stubbles, roots and microbial biomass and ends up in dead soil organic matter during ageing of grassland. In living roots, $\mathrm{N}$ accumulates over time to more than $200 \mathrm{~kg} \mathrm{~N} \mathrm{ha}^{-1}$, however the rate of $\mathrm{N}$ accumulation strongly levels off during ageing of grasslands (Eriksen and Jensen 2001; Whitehead et al. 1990). Stubbles of less than five years contain about $40-80 \mathrm{~kg} \mathrm{~N} \mathrm{ha}^{-1}$ and this amount does not significantly increase with ageing (Davies et al. 2001; Whitehead et al. 1990). The $\mathrm{N}$ content of the soil organic matter of grassland increases approximately linearly in young grasslands ( $<10$ years), ranging from 20 to $130 \mathrm{~kg} \mathrm{~N}$ ha $^{-1}$ year $^{-1}$ (Cuttle and Scholefield 1995; Hassink 1994; Tyson et al. 1990; Whitehead et al. 1990). The accumulation of organic matter levels off during ageing and may continue for more than 30-100 years (Jenkinson 1988). The C/N ratio of the soil organic matter of intensively managed grasslands is commonly in the range of 12-15, but depends on soil type (Whitehead 2000).

Because of the high $\mathrm{N}$ content of grassland soils, renovation may temporary increase the content of mineral $\mathrm{N}$ to more than $200 \mathrm{~kg} \mathrm{~N}^{-1}$ (Davies et al. 2001; Johnston et al. 1994; Lloyd 1992; Shepherd et al. 2001). This increase has been related to three factors. Firstly, stubbles and roots of the grass sward are ploughed into the soil and the net mineralization of these crop residues increases soil mineral $\mathrm{N}$ contents. Secondly, there is a period with no or only small crop uptake of $\mathrm{N}$ after ploughing. This period ranges from several weeks in case of immediately reseeding grassland to several months in case grassland is ploughed in autumn and the following crop is grown in next spring. The third factor is a possible enhanced $\mathrm{N}$ mineralization of soil organic nitrogen because of ploughing. This enhanced $\mathrm{N}$ mineralization is in part related also to the relatively low $\mathrm{C} / \mathrm{N}$ ratio.

The risks of increased $\mathrm{N}$ leaching and nitrous oxide $\left(\mathrm{N}_{2} \mathrm{O}\right)$ emission are relatively high in case the periods with high soil mineral $\mathrm{N}$ contents coincide with wet climatic conditions. For example, it has been reported that leaving the soil fallow after ploughing of grassland resulted in leaching losses of 100-300 kg N ha ${ }^{-1}$ year $^{-1}$ (Adams and Jan 1999; Davies et al. 2001; Lloyd 1992). Bhogal et al. (2000) showed that significant leaching of dissolved organic $\mathrm{N}$ (DON) may occur after ploughing of grassland. Leaching of DON can be a significant $\mathrm{N}$ loss pathway from agriculture (Van Kessel et al. 2009). Davies et al. (2001) showed that ploughing of grassland increased $\mathrm{N}_{2} \mathrm{O}$ emission for several weeks and total $\mathrm{N}_{2} \mathrm{O}$ emissions from ploughed grassland ranged from 1.5 to $3.7 \mathrm{~kg} \mathrm{~N} \mathrm{ha}^{-1}$ year $^{-1}$. Evidently, ploughing up and reseeding grasslands is associated with significantly increased $\mathrm{N}$ losses to surrounding surface waters, groundwater and air, but the empirical evidence for recommending reseeding methods and practices with minimum $\mathrm{N}$ losses are as yet lacking. 
Here, we report on a study that was set up to quantify the agronomic and environmental consequences of methods and time of grassland renovation as function of $\mathrm{N}$ fertilizer application. Field experiments were carried out on three intensively managed grasslands on sand and clay soils in the Netherlands for three years. The experiments were set up to test the following hypotheses:

- grassland renovation increases total herbage yield over a three year period;

- grassland renovation in spring results in less $\mathrm{N}$ leaching than in autumn;

- grassland renovation increases leaching of DON and emissions of $\mathrm{N}_{2} \mathrm{O}$, especially when done in autumn; and

- grassland renovation without ploughing (i.e. grass is only chemically killed) results in less leaching and $\mathrm{N}_{2} \mathrm{O}$ emission than renovation with ploughing.

\section{Materials and methods}

Experimental design

Three identical experiments were carried out for three years (2002-2004) on intensively managed grasslands on sandy soils in Heino $\left(52^{\circ} 26^{\prime} \mathrm{N}, 6^{\circ} 13^{\prime} \mathrm{E}\right)$ and Maarheeze $\left(51^{\circ} 18^{\prime} \mathrm{N}, 5^{\circ} 36^{\prime} \mathrm{E}\right)$ and on a heavy clay soil in Goutum $\left(53^{\circ} 10^{\prime} \mathrm{N}, 5^{\circ} 48^{\prime} \mathrm{E}\right)$. Properties of the soils are presented in Table 1. The permanent grasslands were renovated (i.e. ploughed and reseeded) 10, 6, and 8 years before the experiments started in Heino, Maarheeze and Goutum, respectively.
The experiments were set up as a split-plot design with two replicates. The main treatments were the renovation treatments and the sub treatments were the $\mathrm{N}$ application rates. There were six renovation treatments (T1-T6) and four $\mathrm{N}$ application treatments (N1-N4). The following renovation treatments were included:

- reference treatment, i.e. no renovation (T1);

- grassland chemically killed, ploughed to $25 \mathrm{~cm}$ and reseeded in April 2002 (T2);

- grassland chemically killed, ploughed to $25 \mathrm{~cm}$ and reseeded in September 2002 (T3);

- grassland chemically killed, ploughed to $25 \mathrm{~cm}$ in September 2002 and reseeded in April 2003 (T4);

- grassland chemically killed and reseeded without ploughing in September 2002 (T5); and

- grassland chemically killed, ploughed to $25 \mathrm{~cm}$ and reseeded in April 2003 (T6). This treatment was a repetition of treatment $\mathrm{T} 2$ in 2002.

There were four target $\mathrm{N}$ application treatments, viz. $0(\mathrm{~N} 1), 150(\mathrm{~N} 2), 300(\mathrm{~N} 3)$, and $450(\mathrm{~N} 4) \mathrm{kg} \mathrm{N}$ $\mathrm{ha}^{-1}$ year $^{-1}$ as mineral fertilizer (Calcium ammonium nitrate), split applied in four to six portions per year. The actual applied amounts differed from the target application rates, because of adjustments to the renovation treatment and growing conditions. The average $\mathrm{N}$ application rate for $\mathrm{N} 2$ ranged from $140-170 \mathrm{~kg} \mathrm{~N} \mathrm{ha}{ }^{-1}$ year $^{-1}$, for N3 from 250-310 kg N ha year $^{-1}$ and for N4 from 370-480 kg N ha ${ }^{-1}$ year $^{-1}$. Phosphorus (P) and potassium $(\mathrm{K})$ were applied according to fertilizer recommendations. The $\mathrm{K}$ rates ranged from 60 to $240 \mathrm{~kg} \mathrm{~K}_{2} \mathrm{O}$ ha $^{-1}$ as $\mathrm{KCl}(60 \%)$ and the $\mathrm{P}$ rates ranged from 50 to $135 \mathrm{~kg} \mathrm{P}_{2} \mathrm{O}_{5} \mathrm{ha}^{-1}$ as triple super
Table 1 Soil properties of the three experimental sites

a Water extractable P (soil to water ratio $1: 60 \mathrm{v} / \mathrm{v}$ )

\begin{tabular}{llccccc}
\hline & Time & Layer $(\mathrm{cm})$ & Treatment & Heino & Maarheeze & Goutum \\
\hline Total C $\left(\mathrm{g} \mathrm{kg}^{-1}\right)$ & April 2002 & $0-20$ & $\mathrm{~T} 1$ & 22.1 & 23.6 & 37.7 \\
Total N $\left(\mathrm{g} \mathrm{kg}^{-1}\right)$ & April 2002 & $0-20$ & $\mathrm{~T} 1$ & 1.33 & 1.24 & 3.39 \\
Total P $\left(\mathrm{g} \mathrm{kg}^{-1}\right)$ & April 2002 & $0-20$ & $\mathrm{~T} 1$ & 0.51 & 0.40 & 0.65 \\
$\mathrm{Pw}^{\mathrm{a}}\left(\mathrm{mg} \mathrm{P}_{2} \mathrm{O}_{5} \mathrm{l}^{-1}\right)$ & April 2002 & $0-20$ & $\mathrm{~T} 1$ & 42 & 28 & 16 \\
$\mathrm{pH}-\mathrm{KCl}$ & April 2002 & $0-20$ & $\mathrm{~T} 1$ & 5.7 & 5.9 & 6.6 \\
Dry bulk density $\left(\mathrm{g} \mathrm{cm}^{-3}\right)$ & October 2002 & $10-15$ & $\mathrm{~T} 1$ & 1.42 & 1.44 & 1.24 \\
& & & $\mathrm{~T} 2$ & 1.32 & 1.30 & 1.25 \\
& & & $\mathrm{~T} 3$ & 1.35 & 1.36 & 1.17 \\
& & & $\mathrm{~T} 5$ & 1.41 & 1.42 & 1.34 \\
\hline
\end{tabular}


phosphate. A BG3 mixture containing $100 \%$ perenial ryegrass (Lolium perenne L.) was used for reseeding the renovation treatments. In the third week after emergence the plots were treated with herbicides.

\section{Crop measurements}

The botanical composition of all treatments was characterized once in November 2003. Grass was harvested four to six times per year by mowing to a height of $5 \mathrm{~cm}$ using a Haldrup plot harvester. The time of mowing was dependent on the estimated dry matter yields, according to common practice in the Netherlands. The target yields ranged from $3,500 \mathrm{~kg}$ dry matter ha ${ }^{-1}$ in the first cut to $2,000 \mathrm{~kg} \mathrm{ha}^{-1}$ in the fifth cut. The target dry matter yield of the first cut after reseeding was $1,700 \mathrm{~kg} \mathrm{ha}^{-1}$. Because mowing was dependent on estimated target yields, the dates at which the plots were mown differed between the treatments. The fresh yield of each subplot was determined in the field, using the Haldrup harvester. A grass sample was taken for analyses of dry matter and $\mathrm{N}$ contents.

\section{Soil measurements}

Soil samples were taken of the 0-30, 30-60, and 60-90 cm layers from selected treatments following each harvest, in order to assess the effects of the treatments on accumulation and leaching of mineral $\mathrm{N}$ and DON. All samples were taken per subplot (i.e. in duplicate). Samples were taken at the end of each cut. The content of mineral $\mathrm{N}$ in the upper $90 \mathrm{~cm}$ layer of sandy soils in October-November was used as indicator for nitrate leaching to the groundwater during winter (Ten Berge et al. 2004).

The soil of the treatments $\mathrm{T} 1$ and $\mathrm{T} 2$ and the N1, $\mathrm{N} 2$, and N3 treatments was sampled in duplicate five times during the period May-August 2002. The renovation treatments $\mathrm{T} 1, \mathrm{~T} 2, \mathrm{~T} 3, \mathrm{~T} 4$, and $\mathrm{T} 5$ were also sampled in September 2002, November 2002 and January 2003. The soil of the T1 and T6 treatments was sampled seven times in the period April-August 2003. The results of 2002, showed no significant differences in mineral $\mathrm{N}$ contents between the $\mathrm{N}$ application rates, and, therefore, in 2003 and
2004 only the treatments of N3 were sampled (the most common application rate in practice).

Soil samples were immediately dried at $40^{\circ} \mathrm{C}$, and than ground and sieved. Portions of the dried soils were extracted with $0.01 \mathrm{M} \mathrm{CaCl}_{2}$ (1:10 mass ratio) for $2 \mathrm{~h}$ by gently shaking, and than centrifuged at $1,800 \mathrm{~g}$ according to methods described by Houba et al. (2000). Concentrations of $\mathrm{NH}_{4}{ }^{+}, \mathrm{NO}_{3}{ }^{-}$and DON were measured using standard segmented-flow analysis techniques (Houba et al. 2000). The content of DON is calculated as the difference between the contents of total $\mathrm{N}$ and mineral $\mathrm{N}$. Dissolved organic $\mathrm{C}$ (DOC) in the $0.01 \mathrm{M} \mathrm{CaCl}_{2}$ extract was determined using a TOC/DOC analyzer (Houba et al. 2000). Dry bulk density was measured on undisturbed soil samples in $100 \mathrm{~cm}^{3}$ metal rings taken from the 10 $15 \mathrm{~cm}$ layers of the renovation treatments $\mathrm{T} 1, \mathrm{~T} 2, \mathrm{~T} 3$, and $\mathrm{T} 5$ and $\mathrm{N}$ treatment $\mathrm{N} 3$ in duplicate once in October 2002.

Nitrous oxide emissions measurements

Nitrous oxide fluxes were measured 25-30 times in the period between 4 September 2002 and 17 October 2003. Unfortunately, measurements did not start at the beginning of the experiment in April 2002 because of organizational reasons. Fluxes were measured more intensively in the period just after grassland renovation (up to 4 times per week) and less frequently in the winter (at least once per month).

Fluxes of $\mathrm{N}_{2} \mathrm{O}$ were measured using a closed flux chamber technique, as described by Schils et al. (2008). The chambers (PVC cylinders) had a diameter of $18.6 \mathrm{~cm}$ and height of $15 \mathrm{~cm}$ (after inserting $3 \mathrm{~cm}$ into the soil). The concentration of $\mathrm{N}_{2} \mathrm{O}$ in the headspace was measured just after closing and after $30 \mathrm{~min}$, using a photo-acoustic infra-red gasmonitor of Innova. The analyzer was directly attached to the chambers with polytetrafluorethylene tubes with an internal diameter of $0.3 \mathrm{~cm}$ and a length of $400 \mathrm{~cm}$. A trap of soda lime was attached in the air stream to the gas analyzer to reduce the $\mathrm{CO}_{2}$ concentration and to minimize possible interference of $\mathrm{CO}_{2}$ on the $\mathrm{N}_{2} \mathrm{O}$ measurement. The measured $\mathrm{N}_{2} \mathrm{O}$ concentrations of the headspace were corrected for the internal volume of analyzer and tubes, which was about $2.5 \%$ of the headspace volume. The flux was calculated assuming linear changes of the $\mathrm{N}_{2} \mathrm{O}$ concentration in the 
headspace over time, as shown by Velthof and Oenema (1995). Mean fluxes per treatment were based on four flux measurements (two chambers per plot, two plots per treatment).

\section{Statistical analyses}

The effects of renovation and $\mathrm{N}$ application treatments on grass yields were assessed with the REML-algorithm (Residual Maximum Likelyhood) in Genstat (Genstat Committee 2005), using one statistical model for all treatments, years and sites. The model consisted of a fixed and a random part. In the fixed part of the model, parameters were included that predict the yield and in the random part parameters that caused deviations by random effects (such as effects of year, and heterogeneity variation in the field). Only significant terms $(\alpha=0.05)$ were included in the model. The final model was a model which was used to assess the effect of renovation treatment and fertilizer application on yield, corrected for random factors. The dry matter yield was described with a quadratic function of $\mathrm{N}$ application:

$$
\begin{aligned}
Y_{(\mathrm{t}, \mathrm{y}, \mathrm{N})}= & \beta_{0(\mathrm{t}, \mathrm{y})}+\beta_{1(\mathrm{t}, \mathrm{y})} \times \mathrm{N}+\beta_{2(\mathrm{t}, \mathrm{y})} \times \mathrm{N}^{2} \\
& +\varepsilon_{1}+\varepsilon_{\mathrm{ly}}+\varepsilon_{\mathrm{lb}}+\varepsilon_{\mathrm{lby}}+\varepsilon_{\mathrm{lbp}}+\varepsilon_{\mathrm{lbpy}}
\end{aligned}
$$

where $Y$ is the dry matter yield in $\mathrm{Mg} \mathrm{ha}^{-1}$, as function of year $\mathrm{y}$, renovation method $\mathrm{t}$ and $\mathrm{N}$ application rate $\mathrm{N}$ (in $\mathrm{kg} \mathrm{N} \mathrm{ha}^{-1}$ year $^{-1}$ ), $\beta_{0}$ (t, y) is the dry matter yield in $\mathrm{Mg} \mathrm{ha}^{-1}$, as function of year $\mathrm{y}$ and renovation method $\mathrm{t}$ at $0 \mathrm{~kg} \mathrm{~N}^{-1}$ year $^{-1}, \beta_{1 \text { (t, }}$ y) and $\beta_{2(\mathrm{t}, \mathrm{y})}$ are the $\mathrm{N}$ response coefficients in kg dry matter $\mathrm{kg}^{-1}$ applied $\mathrm{N} \mathrm{ha}^{-1}$, as function of year $\mathrm{y}$ and renovation method $t$. The effects of location $\left(\varepsilon_{1}\right)$, the interaction of location.year $\left(\varepsilon_{\mathrm{ly}}\right)$, the interaction of location.block $\left(\varepsilon_{\mathrm{lb}}\right)$, the interaction of location.block $\cdot y e a r\left(\varepsilon_{\mathrm{lby}}\right)$, and the interactions of loca-

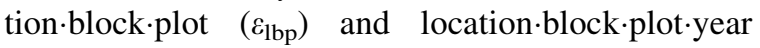
$\left(\varepsilon_{\text {lbpy }}\right)$ were described as deviations caused by random effects. A similar model was used for the assessment of effects of renovation method and $\mathrm{N}$ application on $\mathrm{N}$ yields.

The effect of the treatments on contents of mineral $\mathrm{N}$ and DON in the 0-90 cm layer in autumn of 2002 was assessed by Analysis of Variance (ANOVA) and Least Significant Difference (LSD) at $P<0.05$. Differences in $\mathrm{N}_{2} \mathrm{O}$ emission between the treatments at each site were statistically assessed by ANOVA and LSD at $P<0.05$. All statistical analyses were carried out with the statistical package Genstat (Genstat Committee 2005).

\section{Results}

Botanical composition of the sward and dry matter and nitrogen yields

The percentage of perennial ryegrass in the reference sward was low in November 2002, ranging from $48 \%$ in Maarheeze to $70 \%$ in Goutum. Other important plant species were rough-stalked meadow grass (Poa triviallis L.; 13-19\%) and dandelion (Taraxacum officinale; $1-9 \%$ ). Renovation increased the percentage of perennial ryegrass up to $90 \%$ and more. In Maarheeze and Goutumn, the percentage of perennial ryegrass was smaller after renovation in autumn without ploughing (60-84\%) than with ploughing.

There were statistically significant effects of renovation treatment and $\mathrm{N}$ application rate on dry matter yields. One statistical model was derived for all sites, because there were no statistically significant differences between the three sites. In 2002, dry matter yields were smaller for the renovated treatments T2-T5 than for the reference treatment T1 (Table 2). This is due to the fact that there are one to two harvests less in renovated grassland than in the reference grassland. In 2003 and 2004, the yields of the renovated treatments were generally higher than that of reference treatment. However, averaged over the three years (2002-2004), the dry matter yields were higher for the reference grassland (T1) than for the renovated grasslands (T2-T6). The loss in dry matter yield in the year of renovation was not compensated by yield increases in the reseeded grasslands in the years following renovation. The average $\mathrm{N}$ yields of grassland renovated in spring in 2002-2004 were similar to those of the reference grasslands (Table 3). The $\mathrm{N}$ yields of grassland renovated in autumn were $12-28 \%$ lower than those of the reference grasslands. Table 3 shows that the apparent $\mathrm{N}$ recovery (ANR) of applied $\mathrm{N}$ fertilizer was smaller in the renovation than in the reference treatments, especially at low $\mathrm{N}$ application rate. 
Table 2 Dry matter yields (in $\mathrm{Mg} \mathrm{ha}{ }^{-1}$ year $^{-1}$ ) as function of renovation treatment, $\mathrm{N}$ application treatment and year

\begin{tabular}{|c|c|c|c|c|c|c|c|}
\hline \multirow{3}{*}{$\begin{array}{l}\text { Table } 2 \text { Dry matter yields } \\
\text { (in } \mathrm{Mg} \mathrm{ha}^{-1} \text { year }^{-1} \text { ) as } \\
\text { function of renovation } \\
\text { treatment, } \mathrm{N} \text { application } \\
\text { treatment and year }\end{array}$} & \multirow[t]{2}{*}{ Year } & \multirow[t]{2}{*}{$\mathrm{N}$ rate $\left(\mathrm{kg} \mathrm{N} \mathrm{ha}{ }^{-1}\right.$ year $\left.^{-1}\right)$} & \multicolumn{5}{|c|}{ Renovation treatment } \\
\hline & & & $\mathrm{T} 1$ & T2/T6 & $\mathrm{T} 3$ & $\mathrm{~T} 4$ & $\mathrm{~T} 5$ \\
\hline & \multirow[t]{4}{*}{2002} & 0 & 6.4 & 5.0 & 4.7 & 4.7 & 4.7 \\
\hline & & 150 & 10.3 & 8.0 & 7.6 & 7.6 & 7.6 \\
\hline & & 300 & 13.1 & 9.9 & 9.7 & 9.7 & 9.7 \\
\hline & & 450 & 14.9 & 10.7 & 11.0 & 11.0 & 11.0 \\
\hline & \multirow[t]{4}{*}{2003} & 0 & 6.0 & 5.9 & 5.4 & 5.0 & 5.5 \\
\hline & & 150 & 9.4 & 9.5 & 9.3 & 8.3 & 9.5 \\
\hline & & 300 & 11.6 & 12.0 & 12.1 & 10.5 & 12.5 \\
\hline & & 450 & 12.8 & 13.5 & 13.8 & 11.6 & 14.3 \\
\hline & \multirow[t]{4}{*}{2004} & 0 & 5.5 & 6.7 & 4.8 & 4.8 & 6.0 \\
\hline & & 150 & 9.2 & 10.1 & 9.0 & 9.0 & 9.7 \\
\hline & & 300 & 11.7 & 12.5 & 12.1 & 12.1 & 12.3 \\
\hline & & 450 & 13.2 & 13.8 & 14.1 & 14.1 & 13.9 \\
\hline & \multirow[t]{4}{*}{ Average 2002-2004 } & 0 & 6.0 & 5.9 & 5.0 & 4.9 & 5.4 \\
\hline & & 150 & 9.6 & 9.2 & 8.6 & 8.3 & 8.9 \\
\hline \multirow{2}{*}{$\begin{array}{l}\text { Results of the statistical } \\
\text { model (Eq. 1; see text) }\end{array}$} & & 300 & 12.2 & 11.5 & 11.3 & 10.8 & 11.5 \\
\hline & & 450 & 13.6 & 12.7 & 13.0 & 12.2 & 13.1 \\
\hline
\end{tabular}

Results of the statistical model (Eq. 1; see text)
Table 3 Average $\mathrm{N}$ yields ( $\mathrm{N}$ yield, in $\mathrm{kg} \mathrm{N} \mathrm{ha}^{-1} \mathrm{year}^{-1}$ ) and apparent $\mathrm{N}$ recovery (ANR, in \%) for 2002-2004 for the reference grassland (T1), grassland renovated in spring (T2/
T6), and grassland renovated in autumn (T3/T4/T5), calculated with the statistical model

\begin{tabular}{|c|c|c|c|c|c|c|}
\hline \multirow[t]{2}{*}{$\mathrm{N}$ rate $\left(\mathrm{kg} \mathrm{N} \mathrm{ha}^{-1}\right.$ year $\left.^{-1}\right)$} & \multicolumn{2}{|l|}{$\mathrm{T} 1$} & \multicolumn{2}{|l|}{ T2/T6 } & \multicolumn{2}{|c|}{ T3/T4/T5 } \\
\hline & $\mathrm{N}$ yield & ANR & $\mathrm{N}$ yield & ANR & $\mathrm{N}$ yield & ANR \\
\hline 0 & 132 & & 127 & & 95 & \\
\hline 150 & 233 & 0.67 & 227 & 0.43 & 195 & 0.44 \\
\hline 300 & 328 & 0.65 & 321 & 0.59 & 287 & 0.60 \\
\hline 450 & 417 & 0.63 & 409 & 0.68 & 369 & 0.67 \\
\hline
\end{tabular}

Apparent nitrogen recovery, $\%=\left[(\mathrm{N}\right.$ yield fertilized treatment $)-\left(\mathrm{N}\right.$ yield at $\left.\left.0 \mathrm{~kg} \mathrm{~N}^{-1}\right)\right] / \mathrm{N}$ application rate $\left(\mathrm{kg} \mathrm{N}^{-1}\right) \times 100$

\section{Contents of soil mineral $\mathrm{N}$}

Soil mineral $\mathrm{N}$ contents strongly increased after grassland renovation, for several weeks to months as indicated in Fig. 1 for renovation in spring. In November 2002, the mineral $\mathrm{N}$ contents of the grasslands that were renovated in spring (T2) were similar to those of the reference grassland (Fig. 1; Table 4). However, the mineral $\mathrm{N}$ contents of grassland renovated in autumn (T3, T4, and T5) were significantly higher than those of the reference grassland and the grassland renovated in spring (Fig. 1; Table 4). Mineral $\mathrm{N}$ contents were highest in the treatment $\mathrm{T} 4$, in which reseeding of grassland was postponed to spring 2003. The high mineral $\mathrm{N}$ contents in the 30-60 and $60-90 \mathrm{~cm}$ layers of grasslands renovated in September (T3, T4, and T5) point at $\mathrm{N}$ leaching. There were no differences in mineral $\mathrm{N}$ contents in autumn 2002 between the different $\mathrm{N}$ application rates (not shown). In 2003 and 2004, the differences in mineral $\mathrm{N}$ contents in autumn between the renovation treatments were small (Fig. 2).

\section{Contents of DON in soil}

The contents of DON were higher in the clay soil $\left(>100 \mathrm{~kg} \mathrm{~N} \mathrm{ha}^{-1}\right.$ ) than in the sandy soils (about 60 $80 \mathrm{~kg} \mathrm{~N} \mathrm{ha}^{-1}$; Table 4). In the clay soil, DON 

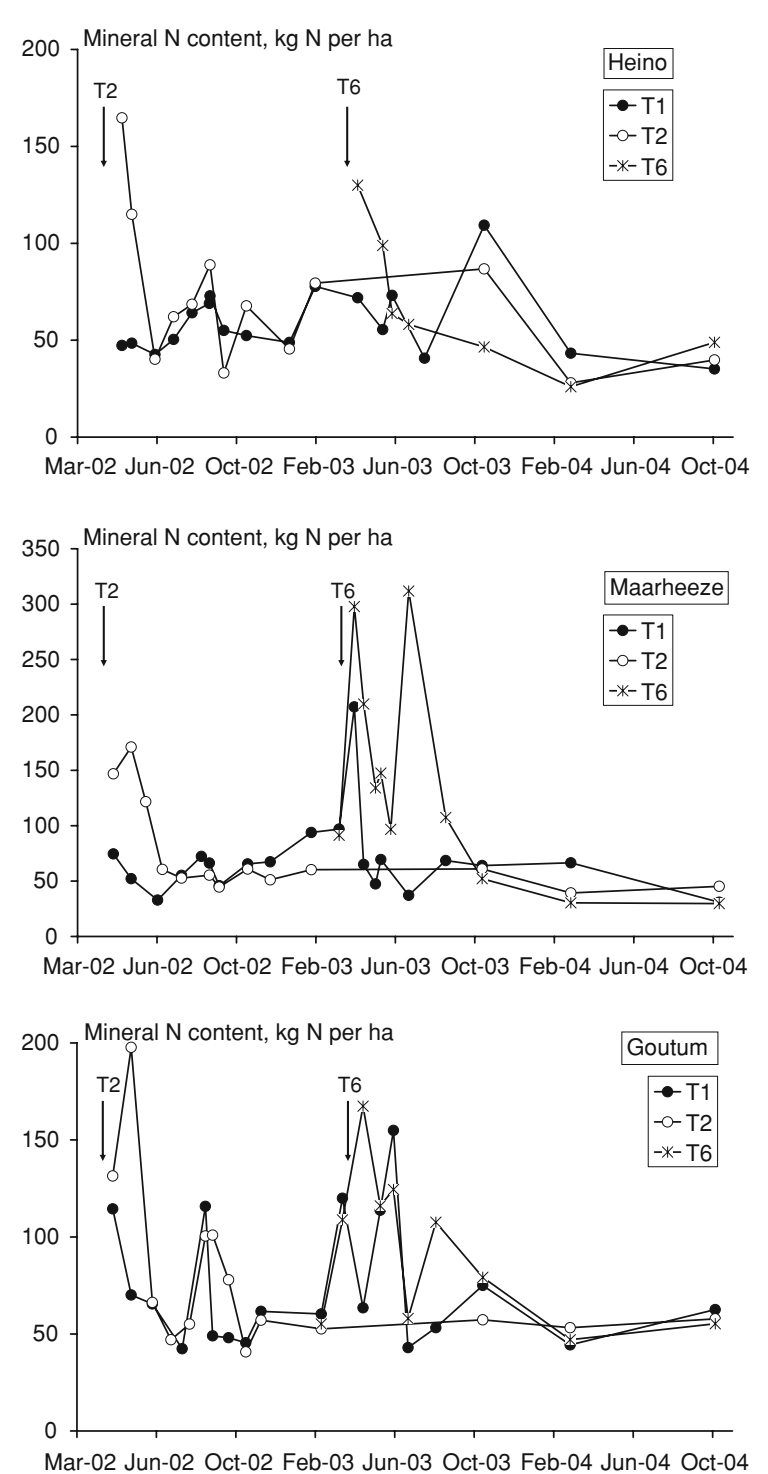

Fig. 1 Time course of mineral $\mathrm{N}$ contents in the $0-90 \mathrm{~cm}$ soil layers for reference grassland (T1), and grassland renovated in spring 2002 (T2) and spring 2003 (T6) at N application rate treatment N3. Arrows indicate time of renovation. Note differences in scale of the $Y$-axes

contents were higher than the mineral $\mathrm{N}$ contents, while in the sandy soils DON was similar to or lower than mineral N. Grassland renovation did not significantly change DON contents during the growing season (not shown) and in autumn (Table 4). There was also no effect of renovation treatment on DON content in the $30-60$ and $60-90 \mathrm{~cm}$ layers (not shown), indicating that there were no differences in DON leaching between the treatments. Also for DOC
Table 4 Average mineral $\mathrm{N}$ and DON contents in $\mathrm{kg} \mathrm{N}^{-1}$ ( $n=6$; three $\mathrm{N}$ application rates in duplicate) in the $0-90$ soil layers in November 2002

\begin{tabular}{llrrrrr}
\hline & Site & \multicolumn{6}{c}{ Renovation treatment } \\
\cline { 3 - 7 } & & T1 & T2 & T3 & T4 & T5 \\
\hline Mineral N & Heino & $73^{\mathrm{a}}$ & $55^{\mathrm{a}}$ & $130^{\mathrm{b}}$ & $214^{\mathrm{c}}$ & $130^{\mathrm{b}}$ \\
$\left(\mathrm{kg} \mathrm{N} \mathrm{ha}^{-1}\right)$ & Maarheeze & $60^{\mathrm{a}}$ & $53^{\mathrm{a}}$ & $137^{\mathrm{b}}$ & $176^{\mathrm{c}}$ & $175^{\mathrm{c}}$ \\
& Goutum & $43^{\mathrm{a}}$ & $40^{\mathrm{a}}$ & $89^{\mathrm{b}, \mathrm{c}}$ & $106^{\mathrm{c}}$ & $64^{\mathrm{a}, \mathrm{b}}$ \\
\multirow{2}{*}{ DON } & Heino & 61 & 58 & 61 & 66 & 61 \\
$\left(\mathrm{~kg} \mathrm{~N} \mathrm{ha}^{-1}\right)$ & Maarheeze & 68 & 79 & 73 & 71 & 71 \\
& Goutum & 148 & 123 & 129 & 134 & 145 \\
\hline
\end{tabular}

Differences in letters per row indicate significant differences in mineral $\mathrm{N}$ contents (LSD test at $P<0.05$ ). There were no significant differences in DON contents

no significant effects of renovation treatments were found (not shown).

Nitrous oxide emissions

Grassland renovation increased $\mathrm{N}_{2} \mathrm{O}$ emissions in all renovation treatments (Fig. 3; Table 5). Fluxes associated with grassland renovation lasted from several weeks to several months. Total $\mathrm{N}_{2} \mathrm{O}$ emissions were on average significantly $(P<0.05)$ higher on the clay soil than on the sandy soils (not shown). When averaged over all sites and renovation treatments, $\mathrm{N}_{2} \mathrm{O}$ emissions increased with increasing $\mathrm{N}$ application rate $(\mathrm{N} 1<\mathrm{N} 2<\mathrm{N} 3)$, but this effect was not statistically significant $(P>0.05$; not shown). Averaged over all sites and $\mathrm{N}$ application rates, renovation increased $\mathrm{N}_{2} \mathrm{O}$ emission statistically significant $(P<0.05)$ with a factor of $1.8-3.0$ in comparison to the reference grassland (Table 5).

Emissions of $\mathrm{N}_{2} \mathrm{O}$ were higher after renovation in spring 2003 than in autumn 2002 (Fig. 3; Table 5). Renovation in autumn without ploughing resulted in a significantly higher $\mathrm{N}_{2} \mathrm{O}$ emission than renovation with ploughing (Fig. 4; Table 5).

In Goutum, $\mathrm{N}_{2} \mathrm{O}$ emissions were higher from unfertilized (N1) renovation treatments $(\mathrm{T} 3, \mathrm{~T} 4, \mathrm{~T} 5$, T2/T6) than from the fertilized (N3) reference treatment. This suggests that the effect of renovation on $\mathrm{N}_{2} \mathrm{O}$ emissions was equivalent to the effect of more than $300 \mathrm{~kg}$ fertilizer $\mathrm{N} \mathrm{ha}^{-1}$ applied to the reference grassland (Table 5). In Heino, $\mathrm{N}_{2} \mathrm{O}$ 

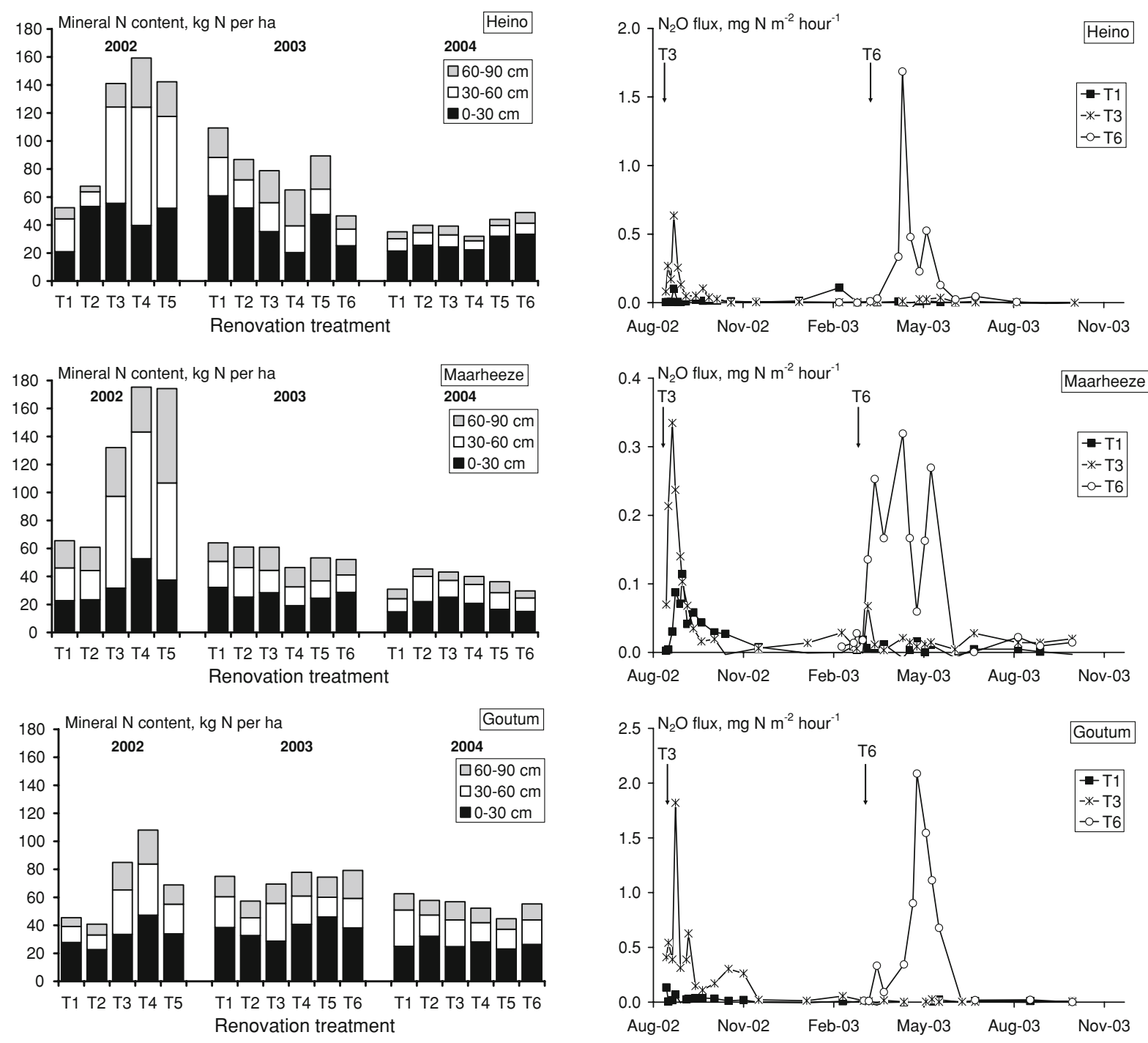

Fig. 2 Mineral $\mathrm{N}$ contents in the 0-30, 30-60, and 60-90 cm soil layers for the different renovation treatments for $\mathrm{N} 3$ in November 2002, 2003 and 2004

emissions associated with renovation in spring were equivalent to the effect of about $150 \mathrm{~kg}$ fertilizer $\mathrm{N} \mathrm{ha}^{-1}$ to the reference grassland ( $\mathrm{T} 1$ and $\mathrm{N} 2$ ). Further, the $\mathrm{N}_{2} \mathrm{O}$ emissions associated with autumn renovation were equivalent to the effect of more than $300 \mathrm{~kg} \mathrm{~N} \mathrm{ha}^{-1}$ applied to reference grassland. In Maarheeze, $\mathrm{N}_{2} \mathrm{O}$ emissions associated with spring renovation were equivalent to the effect of about $75 \mathrm{~kg}$ fertilizer $\mathrm{N} \mathrm{ha}{ }^{-1}$ (intermediate to $\mathrm{N} 1$ and $\mathrm{N} 2$ of $\mathrm{T} 1$ ), while the effects of autumn renovation were

Fig. 3 Time course of $\mathrm{N}_{2} \mathrm{O}$ fluxes for reference grassland (T1), grassland renovated in spring (T6), and grassland renovated in autumn (T3). Grasslands were unfertilized (treatment N1). Arrows indicate time of renovation. Note differences in scale of the $Y$-axes

equivalent to the effect of about $150 \mathrm{~kg}$ fertilizer $\mathrm{N} \mathrm{ha}{ }^{-1}$ applied to reference grassland.

\section{Discussion}

Herbage yields of renovated grassland

The results did not confirm our hypothesis that grassland renovation increases total dry matter 
Table 5 Total $\mathrm{N}_{2} \mathrm{O}$ emission for all treatments and sites in the period 4 September 2002 to 14 October 2003 for Heino and Maarheeze and 17 October for Goutum

\begin{tabular}{|c|c|c|c|c|c|c|c|}
\hline \multirow[t]{2}{*}{ Fertilizer treatment } & \multirow[t]{2}{*}{ Location } & \multicolumn{5}{|c|}{ Renovation treatment $\left(\mathrm{N}_{2} \mathrm{O}\right.$ emission, $\mathrm{kg} \mathrm{N}$ ha $\left.^{-1}\right)$} & \multirow[t]{2}{*}{$\mathrm{LSD}_{0.05}$} \\
\hline & & $\mathrm{T} 1$ & $\mathrm{~T} 3$ & $\mathrm{~T} 4$ & T5 & T2/T6 & \\
\hline N1 & Goutum & 0.8 & 7.9 & 5.8 & 9.7 & 14.4 & \\
\hline N2 & Goutum & 3.2 & 13.4 & 4.1 & 10.8 & 9.8 & \\
\hline N3 & Goutum & 2.7 & 10.8 & 3.9 & 11.8 & 7.3 & \\
\hline N1 & Heino & 1.3 & 2.0 & 4.1 & 6.2 & 7.9 & \\
\hline N2 & Heino & 2.2 & 4.8 & 5.2 & 4.1 & 6.5 & \\
\hline N3 & Heino & 2.1 & 3.2 & 5.9 & 9.8 & 8.9 & \\
\hline N1 & Maarheeze & 1.0 & 2.3 & 5.0 & 4.5 & 4.9 & \\
\hline $\mathrm{N} 2$ & Maarheeze & 4.6 & 4.6 & 5.2 & 4.7 & 6.9 & \\
\hline N3 & Maarheeze & 6.1 & 3.4 & 5.4 & 5.3 & 7.3 & \\
\hline Average & & 2.7 & 5.8 & 4.9 & 7.4 & 8.2 & 1.3 \\
\hline
\end{tabular}

The LSD indicates statistically significant differences in $\mathrm{N}_{2} \mathrm{O}$ emissions between the five renovation treatments $(P<0.05)$

yields over a three year period. The reference grassland had a higher total dry matter yield than the renovated grasslands, despite the relatively poor botanical sward quality of the reference grassland. On the basis of a compilation of results from field experiments in Denmark, Belgium, the Netherlands, United Kingdom, and Ireland, Conijn (2004) concluded that the production increase over a three year period following reseeding is at best more or less equal to the production loss in the year of renovation. Our results and also those summarized by Conijn (2004) are somewhat at stake with the frequent grassland renovation on dairy farms in practice. Conijn (2004) ascribed the contrasting results between practice and experiments to a combination of the following factors: (i) grassland renovation in practice occurs more often than is needed because the perceived benefits are larger than the actual, (ii) in some experiments reseeded grassland has been compared to old grassland that is still in 'a good shape' while farmers only reseed grassland in 'a poor shape', and (iii) substantial differences in yield between reseeded and old grasslands occur especially in dry years on drought-prone soils, because of the better rooting characteristics of the young swards, while experiments not always do reflect these conditions. Another likely explanation is the fact that farmers appreciate especially the improvement of the botanical composition and the associated increase in feeding value of the grass.
The botanical composition in our experiments on sandy soils can be considered as poor according to Dutch recommendations. The botanical composition of the grassland on clay soil can be considered as fair to good. The amount of rainfall was higher in 2002 $(851-1,002 \mathrm{~mm})$ and $2004(789-1,004 \mathrm{~mm})$ than in 2003 (607-656 mm). August 2003 was warm (with temperature up to more than $30^{\circ} \mathrm{C}$ ) and very dry (no rainfall for about 4 weeks). The dry matter yields in the dry year 2003 were higher in the renovation treatments $\mathrm{T} 2$ and $\mathrm{T} 3$ than in the reference $\mathrm{T} 1$. However, similar effects were shown in the wet year 2004, so that our results do not support the suggestion that the difference in dry matter yield between reseeded and old grasslands is higher in dry years than in wet years.

$\mathrm{N}$ losses associated with grassland renovation

It was hypothesized that grassland renovation in spring results in less $\mathrm{N}$ leaching than renovation in autumn. Our experimental results provide indeed evidence for this hypothesis; soil mineral $\mathrm{N}$ contents in autumn were higher for the autumn treatments than the spring treatment. Moreover, mineral $\mathrm{N}$ contents in the $30-90 \mathrm{~cm}$ soil layer were higher in the autumn renovation treatment than the spring renovation treatment, pointing at increased leaching in the autumn renovation treatment. When grassland was renovated in spring, soil mineral $\mathrm{N}$ contents also increased (Fig. 1), but because of the high $\mathrm{N}$ uptake 

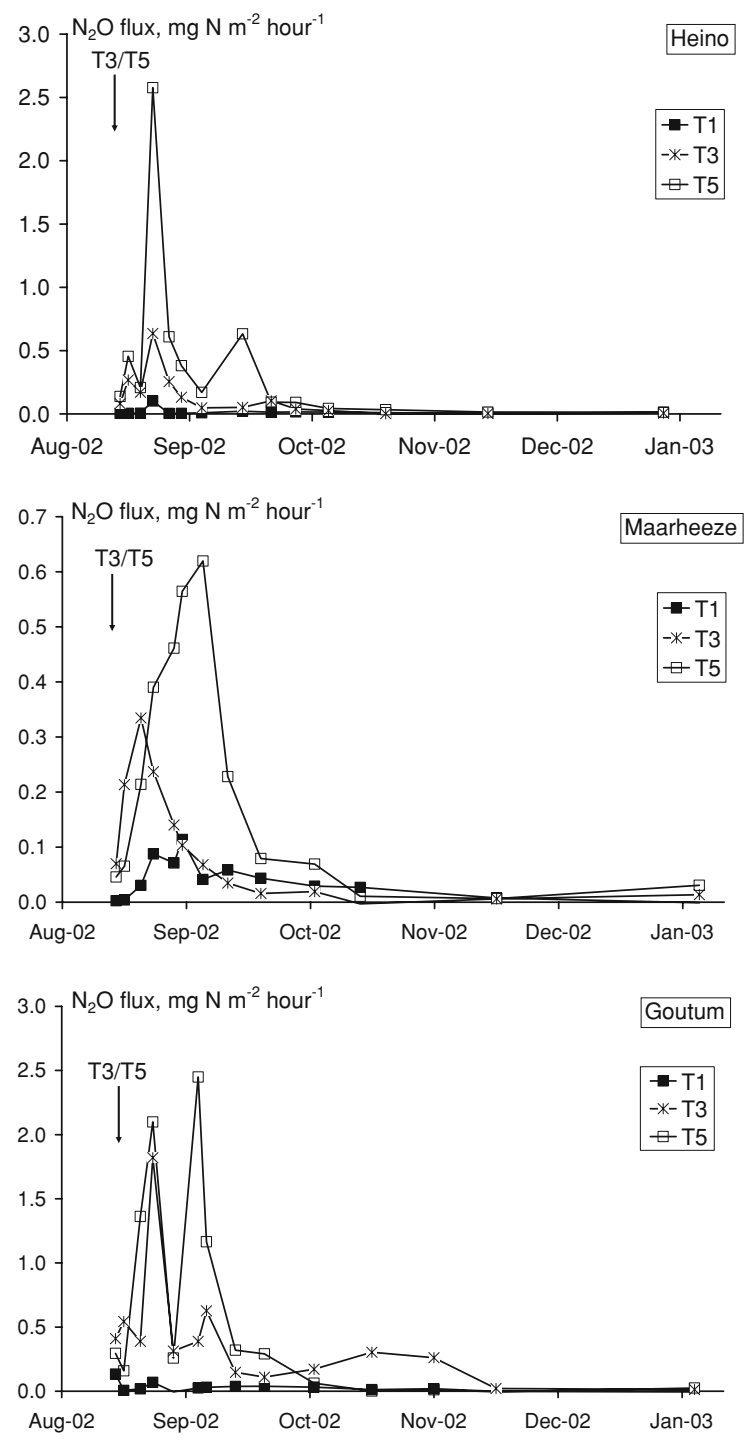

Fig. 4 Time course of $\mathrm{N}_{2} \mathrm{O}$ fluxes in winter 2002/2003 for the reference grassland (T1), and grasslands renovated in autumn 2002 with (T3) and without (T5) ploughing. Grasslands were unfertilized (treatment N1). Arrows indicate time of renovation. Note differences in scale of the $Y$-axes

capacity of the new sward, mineral $\mathrm{N}$ contents decreased again during the growing season. The low ANR in renovated grassland (Table 3) are probably due to the fact that young grasslands allocate a relatively large portion of available $\mathrm{C}$ and $\mathrm{N}$ resources to roots and stubbles and hence less to harvestable aboveground biomass.

Soil mineral $\mathrm{N}$ content in autumn is an indicator for $\mathrm{NO}_{3}{ }^{-}$leaching to the groundwater in the Netherlands. A significant relationship has been found between $\mathrm{NO}_{3}{ }^{-}$contents in the $0-90 \mathrm{~cm}$ soil layer in October/November and the $\mathrm{NO}_{3}{ }^{-}$concentration in the upper groundwater in spring (Ten Berge et al. 2004). Application of the equations of Ten Berge et al. (2004) indicate that autumn renovation in 2002 may have increased $\mathrm{NO}_{3}{ }^{-}$concentrations in the upper groundwater from 40 to $70 \mathrm{mg} \mathrm{NO}_{3}{ }^{-} 1^{-1}$ in Heino and from 58 to $80 \mathrm{mg} \mathrm{NO}_{3}{ }^{-} \mathrm{1}^{-1}$; in Maarheeze. Thus, autumn renovation may result in a substantial increase in the $\mathrm{NO}_{3}{ }^{-}$concentration in the upper groundwater of sandy soil. Shepherd et al. (2001) also observed that ploughing and reseeding in winter resulted in high nitrate leaching. However, ploughing and reseeding in spring had a little effect on $\mathrm{N}$ leaching in comparison to the reference grassland.

Grassland renovation did not result in accumulation and leaching of DON. It has been postulated that DON is an important pool for $\mathrm{N}$ mineralisation, because of the observed relationships between DON contents and $\mathrm{N}$ mineralisation rate (e.g. Murphy et al. 2000). However, Mengel et al. (1999) and Murphy et al. (2000) indicated that the DON pool is less dynamic than the mineral $\mathrm{N}$ pool. That observation is confirmed by our results (not shown), because temporal changes of mineral $\mathrm{N}$ contents were much higher than those of DON. By contrast, Bhogal et al. (2000) showed that grassland renovation significantly increased DON contents over 10 months period. In that study, DON also leached to deeper soil layers. The background of the different behavior of DON in our study and that of Bhogal et al. (2000) is not clear. The mechanisms of the release, decomposition, and transport of DON in soils need further studies.

It was also hypothesized that grassland renovation increases $\mathrm{N}_{2} \mathrm{O}$ emissions and that emissions are higher when renovated in autumn compared to spring. This latter was expected, because conditions are wet in autumn and $\mathrm{N}$ uptake by the reseeded grass low. Renovation increased $\mathrm{N}_{2} \mathrm{O}$ emissions by a factor of 1.8 to 3.0 relative to reference grassland (Table 5). However, mean $\mathrm{N}_{2} \mathrm{O}$ emissions were higher following renovation in spring compared to renovation in autumn. Following renovation in spring, soil mineral $\mathrm{N}$ contents and $\mathrm{N}_{2} \mathrm{O}$ emissions were high during a relatively long period (Fig. 1). In contrast, soil mineral $\mathrm{N}$ contents following renovation in autumn were enhanced for a short period only (not shown). 
Probably, wet conditions in autumn enhanced $\mathrm{NO}_{3}{ }^{-}$ leaching and denitrification, by which soil mineral $\mathrm{N}$ contents and $\mathrm{N}_{2} \mathrm{O}$ emissions rapidly decreased. The total $\mathrm{N}$ losses via $\mathrm{N}_{2} \mathrm{O}$ emissions were relatively small when compared to the total $\mathrm{N}$ input and total $\mathrm{N}$ uptake by the harvested grass. However, Vellinga et al. (2004) indicated that the emission of $\mathrm{N}_{2} \mathrm{O}$ after ploughing of grassland significantly contributes to the total $\mathrm{N}_{2} \mathrm{O}$ emission from agriculture in the Netherlands.

Further, it was hypothesized that grassland renovation without ploughing results in less leaching and $\mathrm{N}_{2} \mathrm{O}$ emissions than renovation with ploughing. Ploughing results in chopping of sward residues into smaller pieces, in a better mixing of the sward residues in the soil, and in a better aeration of the soil. All these factors are conducive to a high mineralization, a strong accumulation of mineral $\mathrm{N}$ in the soil, and therefore to increased risk of $\mathrm{N}$ leaching and $\mathrm{N}_{2} \mathrm{O}$ emissions. However, renovation of grassland without ploughing (i.e. only chemically destruction of the sward) resulted in a higher $\mathrm{N}_{2} \mathrm{O}$ emission than renovation with ploughing. Soil mineral $\mathrm{N}$ contents in autumn were similar for the treatments 'chemical killing and ploughing' and 'chemical killing'. In Maarheeze, soil mineral N contents were even higher after renovation without ploughing than after renovation with ploughing. Arnott and Clement (1966) found that N yields of crops following grassland that was chemically killed (and not ploughed) were similar to those obtained by ploughing (and not chemically killed). Lloyd (1992) concluded that shallow cultivation to about $7.5 \mathrm{~cm}$ depth of grassland leads to similar $\mathrm{N}$ losses than ploughing to a depth of $15-20 \mathrm{~cm}$. Ploughing increases the aeration of soils and this effect may have contributed to the less $\mathrm{N}_{2} \mathrm{O}$ emissions after renovation with ploughing than after renovation without ploughing. The results of the bulk density measurements (Table 1) indeed show a lower bulk density of the upper soil layer in the treatments with ploughing (T2 and T3) compared to treatment without ploughing (T5).

Risk of $\mathrm{NO}_{3}{ }^{-}$leaching was higher in treatments with grassland renovation in autumn compared to grassland renovation in spring, but the opposite was shown for $\mathrm{N}_{2} \mathrm{O}$ emissions. This difference is caused by the different control mechanisms of $\mathrm{N}$ leaching and $\mathrm{N}_{2} \mathrm{O}$ emissions. Nitrous oxide originates from (de)nitrification processes in soil, and its release is enhanced under wet conditions and when sufficiently $\mathrm{NO}_{3}{ }^{-}$and $\mathrm{NH}_{4}{ }^{+}$are present in the soil. These conditions may occur during the whole growing season in intensively managed grassland, especially in periods with rainfall just after $\mathrm{N}$ fertilizer application (e.g. Velthof et al. 1996). By contrast, nitrate leaching to the deeper soil layers only occurs when the amount of precipitation exceeds the evapotranspiration, which is generally in the period September to March in the Netherlands.

\section{Conclusions}

Grassland renovation did not increase total dry matter yields over a three years period, but increased the risk of both $\mathrm{N}$ leaching and $\mathrm{N}_{2} \mathrm{O}$ emission. Losses of $\mathrm{N}$ via leaching and $\mathrm{N}_{2} \mathrm{O}$ emission after renovation can probably not be avoided, but renovation in spring in stead of autumn in combination with proper ploughing and timing of fertilizer application can minimize $\mathrm{N}$ losses. Because of the complexity and the many interactions involved, it is not easy for farmers to define the most appropriated time and method of grassland renovation. This study has provided a basis for improved recommendations to farmers to determine when grassland renovation has beneficial agronomic effects and little environmental impact.

Acknowledgments We thank Willy de Groot, Eduard Hummelink, Henk Gunnink, and Theo van Hattum for the field measurements of nitrous oxide emission. Johan van Riel of Animal Science Group of Wageningen University and Research Centre is acknowledged for the statistical analyses of the yield data. Funding for this study was provided by the Dutch Ministery of Agriculture, Nature and Food Quality (Programme 398-II) and the Reduction Programme Non- $\mathrm{CO}_{2}$ Greenhouse Gases under contract of SENTER NOVEM.

Open Access This article is distributed under the terms of the Creative Commons Attribution Noncommercial License which permits any noncommercial use, distribution, and reproduction in any medium, provided the original author(s) and source are credited.

\section{References}

Adams WA, Jan MT (1999) Utilization of nitrogen accumulated by a clover containing ley following cultivation. Soil Use Manag 15:247-253 
Arnott RA, Clement CR (1966) The use of herbicides in alternative husbandry as a substitute for ploughing. Weed Res 6:142-157

Bhogal A, Murphy DV, Fortune S, Shepherd MA, Hatch DJ, Jarvis SC, Gaunt JL, Goulding KWT (2000) Distribution of nitrogen pools in the soil profile of undisturbed and reseeded grasslands. Biol Fertil Soils 30:356-362

Bos JFF, Pflimlin A, Aarts HFM, Vertès F (eds) (2005) Nutrient management at farm scale. How to attain policy objectives in regions with intensive dairy farming? Plant Research International Report 83, Plant Research International, Wageningen, $260 \mathrm{pp}$

Conijn JG (2004) Crop and animal performance In: Conijn JG, Taube F (eds) Grassland resowing and grass-arable crop rotations consequences for performance and environment. Plant Research International, Wageningen, Report 80, pp 48-65

Cuttle SP, Scholefield D (1995) Management options to limit nitrate leaching from grassland. J Contam Hydrol 20: 299-312

Davies MG, Smith KA, Vinten AJA (2001) The mineralisation and fate of nitrogen following ploughing of grass and grass-clover swards. Biol Fertil Soils 33:423-434

Eriksen J, Jensen LS (2001) Soil respiration, nitrogen mineralisation and uptake in barley following cultivation of grazed grasslands. Biol Fertil Soils 33:139-145

Genstat Committee (2005) The guide to Genstat release 8. Part 2: statistics. VSN International Ltd, Oxford

Hassink J (1994) Effects of soil texture and grassland management on soil organic $\mathrm{C}$ and $\mathrm{N}$ and rates of $\mathrm{C}$ and $\mathrm{N}$ mineralization. Soil Biol Biochem 26:1221-1231

Houba VJG, Temminghoff EJM, Gaikhorst GA, Van Vark W (2000) Soil analysis procedures using $0.01 \mathrm{M}$ calcium chloride as extraction reagent. Commun in Soil Sci Plant Anal 31:1299-1396

Jenkinson DS (1988) Soil organic matter and its dynamics. In: Wild A (ed) Russels's soil conditions and plant growth, 11 th edn. Longman, New York, pp 564-607

Johnston AE, Mc Ewen J, Lane PW, Hewitt MV, Poulton PR, Yeoman DP (1994) Effects of one to six year old ryegrassclover leys on soil requirements of the arable sequence winter wheat, potatoes, winter wheat, winter beans (Vicia faba) grown on a sandy loam soil. J Agric Sci 122:73-89

Lloyd A (1992) Nitrate leaching under arable land ploughed out from grass. In: Proceedings Fertiliser Society 330, $32 \mathrm{pp}$

Mengel K, Schneider B, Kosegarten H (1999) Nitrogen compounds extracted by electroultrafiltration (EUF) or $\mathrm{CaCl} 2$ solution and their relationships to nitrogen mineralization in soils. J Plant Nutr Soil Sci 162:139-148
Murphy DV, Macdonald AJ, Stockdale EA, Goulding KWT, Fortune S, Gaunt JL, Poulton PR, Wakefield JA, Webster CP, Wilmer WS (2000) Soluble organic nitrogen in agricultural soils. Biol Fertil Soils 30:374-387

Schils RLM, Aarts HFM, Bussink DW, Conijn JG, Corré WJ, Van Dam AM, Hoving IE, Van der Meer HG, Velthof GL (2002) Grassland renovation in the Netherlands; agronomic, environmental and economic issues In: Conijn JG, Velthof GL, Taube F (eds) Grassland resowing and grassarable crop rotations Plant Research International, Wageningen, Report 47, pp 9-24

Schils RLM, Van Groenigen JW, Velthof GL, Kuikman PJ (2008) Nitrous oxide emissions from multiple combined applications of fertiliser and cattle slurry to grassland. Plant Soil 310:89-101

Shepherd MA, Hatch DA, Jarvis SC, Bhogal A (2001) Nitrate leaching from reseeded pasture. Soil Use Manag 17:97105

Ten Berge HFM, Burgers SLGE, ten Broeke MJDH, Smit A, De Gruijter JJ, Velthof GL, Schroder JJ, Oenema J, De Ruijter FJ, Radersma S, Hoving IE, Boels D (2004) Nitrogen rate, surplus or residue? Performance of selected indicators for nitrate leaching. In: Hatch DJ, Chadwick DR, Jarvis SC, Roker JA (eds) Controlling nitrogen flows and losses. Wageningen Academic Publishers, Wageningen, pp 397-405

Tyson KC, Roberts DH, Clement CR, Garwood EA (1990) Comparison of crop yields and soil conditions during 30 years under annual tillage or grazed pasture. J Agric Sci 115:29-40

Van Kessel C, Clough T, Van Groenigen JW (2009) Dissolved organic nitrogen: an overlooked pathway of nitrogen loss from agricultural systems? J Environ Qual 38:393-401

Vellinga TV, Van den Pol-van Dasselaar A, Kuikman PJ (2004) The impact of grassland ploughing on $\mathrm{CO}_{2}$ and $\mathrm{N}_{2} \mathrm{O}$ emissions in the Netherlands. Nutr Cycl Agroecosyst 70:33-45

Velthof GL, Oenema O (1995) Nitrous oxide fluxes from grassland in the Netherlands: I. Statistical analysis of flux chamber measurements. Eur J Soil Sci 46:533-540

Velthof GL, Brader AB, Oenema O (1996) Seasonal variations in nitrous oxide losses from managed grasslands in the Netherlands. Plant Soil 181:263-274

Whitehead DC (2000) Nutrient elements in grassland. Soil plant animal relationships. CABI, Wallingford

Whitehead DC, Bristow AW, Lockyer DR (1990) Organic matter and nitrogen in the unharvested fractions of grass swards in relation to the potential for nitrate leaching after ploughing. Plant Soil 123:39-49 